\title{
INFLUENCE OF SINGLE AND SMALL CLUSTERS OF TREES ON THE BIOCLIMATE OF A CITY: A CASE STUDY
}

\author{
by S. Streiling ${ }^{1}$ and $A$. Matzarakis ${ }^{2}$
}

\begin{abstract}
This study examines the effects of single trees and small clusters of trees on the bioclimate of a city. Investigations of the thermal environment and air quality of the urban climate were carried out on September 19 and September 29, 2000, at

Fahnenbergplatz, in the northern city center of Freiburg in southwest Germany. The study area, approximately $1,700 \mathrm{~m}^{2}$, contains 12 horsechestnut trees (Aesculus hippocastanum) of different ages and sizes. The positive effect of trees on the thermal environment and air quality component was confirmed by the study. In particular, the mean radiation temperature $T_{\text {mrt }}$, and the human biometeorological thermal index known as the physiological equivalent temperature (PET) showed distinct differences between areas with trees and areas without trees, despite the small size of the investigation area. A high reduction potential for nitrogen oxides and ozone was found inside the tree crowns, but outside the crowns there was no measurable reduction. The most important result regarding volatile organic compounds (VOCs) was the absence of terpene emissions from the horsechestnuts. Similarly, no isoprene emissions from horsechestnuts were found. Therefore, horsechestnut trees have a very small ozoneforming potential.
\end{abstract}

Key Words. Urban climate; bioclimate, urban trees; thermal component; air quality.

Increasingly, humans spend most of their time in urban areas. Continuous urbanization and the growth of industrial production increase exhausts of waste heat as well as gaseous and solid wastes. As a result, much of humankind is exposed to serious, long-term health stress (Baumüller et al. 1999; Guderian 2000). To minimize urban climatological impairment, many measures can be taken. A popular method is the creation of greenbelts to improve the urban climate. Many studies have been conducted to measure the effectiveness of trees in urban areas (Heisler 1977; Herrington 1977; Bernatzky 1979; Meyer and Bauermel 1982; Oke 1989; Cardelino and Chameides 1990; McPherson et al. 1994; Kiese 1995; Benjamin and Winer 1998; Kuchelmeister 1998; Isidorov et al. 1999; Fuentes et al. 2000; Toll and Baldasano 2000; Karlik and Winer 2001). Urban trees reduce air temperature, increase air humidity, reduce wind speed, adsorb air pollutants $\left(\mathrm{NO}_{\mathrm{x}}, \mathrm{O}_{3}, \mathrm{SO}_{2}, \mathrm{CO}\right.$, VOCs) and particulate matter, reduce $\mathrm{CO}_{2}$, and reduce noise levels. On the other hand, trees are possible emission sources for VOCs and result in higher secondary air pollutants (i.e., ozone) (Guderian 2000).
In this study, experimental investigations were conducted at the Fahnenbergplatz in the northern part of the city center of Freiburg in southwest Germany. The objective of this study was to quantify the thermal and air pollution effects of urban trees on urban climate and human bioclimate in cities.

\section{EXPERIMENTAL SITES AND DATABASE}

The reference sites used in this study are located in the northern city center at the Fahnenbergplatz of Freiburg im Breisgau ( $47^{\circ} 59^{\prime} 30^{\prime \prime} \mathrm{N}, 7^{\circ} 50^{\prime} 60^{\prime \prime} \mathrm{E}$ ). The Fahnenbergplatz is a $1,700 \mathrm{~m}^{2}$ triangular inner-city park. It contains 12 horsechestnut trees (Aesculus hippocastanum) of different ages and sizes. There is a fountain in the center of the park. The park is bordered by two heavily traveled streets, Friedrichstrasse and Rotteckring, and a smaller street.

Freiburg is located at an elevation of $278 \mathrm{~m}$ east of the south Upper Rhine plain at the border of the Black Forest (Stadt Freiburg 2001). The relatively low elevation and latitude of Freiburg results in a mild climate. The annual mean air temperature is $10.5^{\circ} \mathrm{C}(1951-1980)$, and the annual mean precipitation is $933 \mathrm{~mm}$ (Deutscher Wetterdienst 1980). Maps of the region and study site are shown in Figure 1 and Figure 2*.

For the study of the thermal environment, a specially designed mobile carriage was used, which has been applied for other investigations in Freiburg (Matzarakis 2001), Leipzig (Bauer 1999), and Munich (Matzarakis 2001). The mobile carriage has no engine, which is an advantage because it produces no emissions, and it can reach most of the urban microstructures in a city. Measuring points were MP 1 to MP 5 (Figure 2).

The instruments in the mobile carriage measured drybulb $\left(\mathrm{T}_{\mathrm{a}}\right)$ and wet-bulb $\left(\mathrm{T}_{\mathrm{f}}\right)$ temperature (aspiration psychrometer with Pt 100 sensors); wind velocity v (hot wire anemometer, Dantec Corp.); wind direction dd (short twine); shortwave radiation $\mathrm{R}_{\mathrm{k}}$ (pyranometer, type CM 21, Kipp and Zonen Corp.); and longwave radiation $\mathrm{L}_{\mathrm{w}}$ (pyrgeometer, type CG 21, Kipp and Zonen Corp.). Vapor pressure (VP), relative air humidity (RH), mean radiant temperature $\left(\mathrm{T}_{\mathrm{mrt}}\right)$ (VDI 1998; Matzarakis 2001), and physiologically equivalent temperature (PET) were calculated from these measurements (Mayer and Höppe 1987; Höppe 1993; Matzarakis 2001). The PET values were 
calculated with the RayMan model (Matzarakis and Mayer 2000; Matzarakis et al. 2000).

The air quality component was measured with passive sampling devices at measuring points MP 2 to MP 6 (Figure 2). MP 6 was inside a tree crown at approximately $6 \mathrm{~m}$ height. The influence of nitrogen oxides was measured through discoloration of filters with 4-dimethylaminoantrachinon. This discoloring was measured by a color pen (Dr. Lange Corp., Germany). The color pen works according to the color metrical principle. The function principle for ozone is the same, but indigocarmin is used instead of 4dimethylamino-antrachinon. To collect VOCs, a special kind of activated sorption material (Carbotrap, Supelco Corp., U.S.) was used. After being exposed, this material was desorbed by a microwave desorption device connected to a gas chromatograph with a mass selective analyzer.

The investigations were carried out on September 19 and 29,2000. Exposure times were 11 and 12 hours.

\section{RESULTS AND DISCUSSION}

Results for September 29 are presented (Figure 3); those for September 19 were similar. A maximum air temperature difference of $2.2^{\circ} \mathrm{C}$ was recorded between two measuring points for both investigation days. Mean differences in air temperature were $1.0^{\circ} \mathrm{C}$ and $0.9^{\circ} \mathrm{C}$ between areas with trees and areas without trees, respectively. This result is comparable to the values provided in literature (Bernatzky 1979; Oke 1989; Kiese 1995; Amt für Umweltschutz 1999). During both days, air temperature was found to decrease as the number of trees increased. The same phenomenon has been observed in other investigations (Brahe 1974; Bernatzky 1979; Oke 1989; Kiese 1995; Amt für Umweltschutz 1999).

Differences between the single tree (MP 1) and the cluster of trees (MP 3) demonstrated that, on average, there is a $0.1^{\circ} \mathrm{C}$ higher air temperature detectable under the single tree (MP 1) than under the cluster of tree crowns (MP 3). In Figure 3, for example, the diurnal variation of air temperature is illustrated in relation to the variation of air temperature under a cluster of tree crowns (MP 3) on September 29.

Differences in mean relative humidity were 5\% to $7 \%$ between the areas with and without trees, respectively, which was similar to other findings (Kramer and Kozlowski 1970; Bernatzky 1979). Small differences of $1.1 \%$ and $0.9 \%$ were observed between the measuring points under a tree crown (MP 1) and under a cluster of tree crowns (MP 3). In both cases, the measuring point under a cluster of tree crowns (MP 3) showed higher values than under a tree crown (MP 1).

The incoming shortwave radiation from the upper half of the canopy presented maximum differences of $660 \mathrm{~W} / \mathrm{m}^{2}$ and $567 \mathrm{~W} / \mathrm{m}^{2}$, and mean differences of $303 \mathrm{~W} / \mathrm{m}^{2}$ and $294 \mathrm{~W} / \mathrm{m}^{2}$ between the areas with trees and without trees, respectively. Incoming solar radiation was normally at a minimum under a cluster of tree crowns (MP 3) and at a maximum for the street canyon, north side (MP 5) (Figure 4).
Diurnal incoming (Figure 5) and outgoing (Figure 6) longwave radiation are illustrated in relation to the measuring point under a cluster of tree crowns (MP 3). On both investigation days, the longwave radiation shows the differences between areas influenced and not influenced by trees. Due to shade effects, the surface at the measuring points under a tree crown (MP 1) and under a cluster of tree crowns (MP 3) did not receive as much energy from solar radiation as places without shade effects, such as the measuring point street canyon, north side (MP 5).

The influence of trees on the synthetic parameter $T_{\text {mrt }}$ and the human biometeorological thermal index PET was of special interest. $T_{\text {mrt }}$ is the most important parameter in the human energy balance during summer conditions. Maximum differences of $30.8^{\circ} \mathrm{C}$ and $34.1^{\circ} \mathrm{C}$ in $\mathrm{T}_{\text {mrt }}$ were found between places that were heavy and lightly influenced by trees. The maximum mean differences are $19.3^{\circ} \mathrm{C}$ and $21.0^{\circ} \mathrm{C}$, respectively. PET showed maximum differences of $17.6^{\circ} \mathrm{C}$ and $16.6 \mathrm{C}$, whereas in relation to the mean values there were maximum differences of $7.5^{\circ} \mathrm{C}$ and $9.9^{\circ} \mathrm{C}$, respectively (Figure 7 and Figure 8).

Mean reduction of nitrogen oxides and ozone tree crown (MP 6) were $19 \mu \mathrm{g} / \mathrm{m}^{3}$ for $\mathrm{NO}_{\mathrm{x}}$ and $37 \mu \mathrm{g} / \mathrm{m}^{3}$ for $\mathrm{O}_{3}$, respectively, relative to the measuring point at the south side of a street canyon (MP 4)—specifically, reductions of $45 \%$ for nitrogen oxides and 55\% for ozone on September 29. Mean nitrogen oxide and ozone concentrations for all measurement points are shown in Figure 9. Two other investigations show similar reductions for nitrogen oxides (Heggestad 1972) and for ozone (DeSanto et al. 1976; Nowak et al. 2000). Which mechanism, (i.e., dry deposition or stomatal uptake inside the tree crown) is responsible for the air pollution reduction process could not be shown by the investigations. There were no signs indicating that trees increase the ozone concentration.

Regarding VOCs, there was an important result revealed by the current investigation. No isoprene emissions by horsechestnut trees were detected. Furthermore, the VOC results furnished no clear statements of VOC reduction of trees, as also shown by Rasmussen (1978). Finally, no emission of unexpected substances such as aromatics was detected.

\section{CONCLUSIONS}

The study demonstrates that a small group of trees as well as a single tree has positive effects on the thermal and air quality component of the urban climate. Consequently, trees have a considerable positive influence on the urban bioclimate and, as such, they should have a stronger role in the planning of urban structures. It is important to plant and care for trees, especially in inner-city areas. When possible, trees should be planted in clusters. In new plantings, trees with high biogenic VOC emissions should be avoided. 
Future studies should take measurements at different heights for a better understanding of the effects of trees on the surrounding areas. Larger investigation areas and measurements over a longer time could show gradients between more and less tree-influenced areas. More sophisticated measurement procedures are needed for a better understanding of the diurnal patterns of pollutant uptake and emissions, such as with the use of semi-open systems with measurable gas inputs and gas outputs.

\section{LITERATURE CITED}

Amt für Umweltschutz. 1999. Klima-Messungen im Plangebiet Stuttgart 21-Eine Analyse thermisch induzierter Ausgleichsströmungen an innerstädtischen Grünanlagen. Landeshauptstadt Stuttgart, Amt für Umweltschutz, Abt. Stadtklimatologie, Stadtklima Stuttgart, Chapter 1-7 (www.stadtklima.de/stuttgart/ websk21/Heft 12/kap1.HTM).

Bauer, B. 1999. Mikrometeorologische Analyse und Bewertung kleinräumiger Stadtstrukturen. UFZ-Bericht Nr. 3.

Baumüller, J., M.J. Kerschgens, and A. Helbig. 1999. Stadtklima und Luftreinhaltung. 2. Aufl., Springer Verlag, Berlin/Heidelberg, Germany.

Benjamin, M.T., and A.M. Winer. 1998. Estimating the ozone-forming potential of urban trees and shrubs. Atmos. Environ. 32:53-68.

Bernatzky, A. 1979. Grünflächen und Klima. DBZForschung und Praxis. 080 DBZ 8/79:1205-1209.

Brahe, P. 1974. Klimatische Auswirkungen von Gehölzen auf umbauten Stadtplätzen. Das Gartenamt 2/74:61-70.

Cardelino, C.A., and W.L. Chameides 1990. Natural hydrocarbons, urbanization and urban ozone. J. Geophys. Res. 95:13971-13979.

DeSanto, R.S., R.A. Glaser, W.P. McMillen, K.A. MacGregor, and J.A. Miller. 1976. Open Space as an Air Resource Management Measure, Volume II: Design Criteria. EPA 450/3-76-0286. U.S. Environmental Protection Agency, Research Triangle Park, NC.

Deutscher Wetterdienst. 1980. Klimainformationen für den Zeitraum 1951-1980.

Fuentes, J.D., M. Lerdau, R. Atkinson, D. Baldocchi, J. W. Bottenheim, P. Ciccioli, B. Lamb, C. Geron, L. Gu, A. Guenther, T.D. Sharkey, and W. Stockwell. 2000. Biogenic hydrocarbons in the atmospheric boundary layer: a review. Bull. Am. Meteor. Soc. 81:1537-1575.

Guderian, R. (Ed.). 2000. Band 1A: Atmosphäre: Anthropogene und biogene Emissionen - Photochemie der Troposphäre - Chemie der Stratosphäre und Ozonabbau. Springer Verlag, Berlin/Heidelberg, Germany

Heggestad, H.E. 1972. How plants fight "man made" pollution. Sci. Teacher. April:21-24.

Heisler, G.M. 1977. Trees modify metropolitan climate and noise. J. Arboric. 3:201-207.
Herrington, L.P. 1977. The role of the urban forests in reducing urban energy consumption. Proc. Soc. Am. For., 60-66.

Höppe, P.R. 1993. Heat balance modelling. Experientia 49:741-746.

Isidorov, V., J. Jaroszynska, T. Sacharewicz, and E. Piroznikow. 1999. Natural VOC emissions from forests in Poland. Atmos. Environ. 33:4739-4744.

Karlik, J.F, and A.M. Winer 2001. Measured isoprene emission rates of plants in California landscapes: comparison to estimates from taxonomic relationships. Atmos. Environ. 35:1123-1131.

Kiese, O. 1995. Die bioklimatische Funktion innerstädtischer, insbesondere baumbestandener Grünflächen. Verhandlungen der Gesellschaft für Ökologie 24:395-401.

Kramer, P.J., and T.T. Kozlowski. 1970. Physiology of Trees. McGraw-Hill, New York, NY.

Kuchelmeister, G. 1998. Tree City-Urban Forestry in the Asia-Pacific Region: Status and Prospects . APFSOS (AsiaPacific Forestry Sector Outlook Study). FAO, Forestry Policy and Planing Division, Working Paper No. 44. Rome, Italy.

Matzarakis, A. 2001. Die thermische Komponente des Stadtklimas. Ber. Meteorol. Inst. Univ. Freiburg. Nr. 6.

Matzarakis, A., and Mayer, H. 2000. Atmospheric conditions and human thermal comfort in urban areas. Proc. 11th Sem. Environmental Protection, "Environment and Health," Thessaloniki, 155-165.

Matzarakis, A., F. Rutz, and H. Mayer. 2000: Estimation and calculation of the mean radiant temperature within urban structures, pp 273-278. In de Dear, R.J., J.D. Kalma, T.R. Oke, and A. Auliciems (Eds.). Biometeorology and Urban Climatology at the Turn of the Millenium: Selected Papers from the Conference ICB-ICUC'99, Sydney, WCASP-50, WMO/TD No. 1026.

Mayer H., and P. Höppe. 1987. Thermal comfort of man in different urban environments. Theor. Appl. Climatol. 38:43-49.

McPherson, E.G., D.J. Nowak, and R.A. Rowantree (Eds.). 1994. Chicago's Urban Forest Ecosystem: Results of the Chicago Urban Forest Climate Project. Gen. Tech. Rep. NE-186, Department of Agriculture, Forest Service, Northeastern Forest Experiment Station, Radnor, PA.

Meyer, F.H., and G. Bauermel 1982. Bäume in der Stadt. Eugen Ulmer Verlag, Stuttgart, Germany.

Nowak, D.J., K.L. Civerolo, S.T. Rao, G. Sistla, C.J. Luley, and D.E. Crane 2000. A modeling study of the impact of urban trees on ozone. Atmos. Environ. 34:1601-1613.

Oke, T.R. 1989. The micrometeorology of the urban forest. Phil. Trans. R. Soc. Lond. 324:335-349.

Rasmussen, R.A. 1978. Isoprene Plant Species List. Special Report of theAir Pollution Research Section, Washington State University, Pullman, WA.

Stadt Freiburg. 2001: Wirtschaft und Standortdaten der Stadt Freiburg im Breisgau (www.freiburg.de/3/3/300/ zahlen.php?rubrik). 
Toll, I., and J.M. Baldasano. 2000. Modeling of photochemical air pollution in the Barcelona area with highly disaggregated anthropogenic and biogenic emissions. Atmos. Environ. 34:3069-3084.

VDI. 1998. VDI 3787, Part I: Environmental Meteorology, Methods for the Human Biometeorological Evaluation of Climate and Air Quality for the Urban And Regional Planning at Regional Level. Part I: Climate. Beuth, Berlin, Germany. 29 pp.

Acknowledgments. This review was supported with data from UMEG Umweltmessungen-Umwelterhebungen und Gerätesicherheit Company, Karlsruhe, Germany. We would also like to thank the staff of the Meteorological Institute of the University of Freiburg for supporting us during the measurement periods.

\section{${ }_{1,2^{*}}$ Meteorological Institute \\ University of Freiburg \\ Werderring 10 \\ D-79085 Freiburg, Germany}

\section{*Corresponding author: Andreas Matzarakis}

Résumé. Cette étude examine quelques effets des arbres singuliers et de petites groupes d'arbres sur le bioclimat d'une ville. Des mesures météorologiques ont été faits pour obtenir des composantes du climat urbain, soit thermiques ou de la qualité de l'air sur une place urbaine le 19 et le 29 septembre 2002. Cette place s'appelle Fahnenbergplatz et se trouve dans le centre nord de la ville de Freiburg qui est située au sudouest d'Allemagne. La surface de l'investigation avait une grandeur de $1700 \mathrm{~m}^{2}$ et est occupée de douze châtaigniers (Aesculus hippocastanum) de différents âges et tailles. On pourrait confirmer des effets positifs des arbres sur la composante thermique et la composante de la qualité de l'air du climat urbain. La température radiative moyenne $\left(T_{\text {mrt }}\right)$ et l'indice thermique bio-météorologique humain (température physiologiquement équivalente PET) montrait des différences considérables en relation des superficies avec des arbres et des surfaces non occupées en dépit de l'élargissement des plans d'échantillon. On a trouvé un potentiel élevé pour les oxydes d'azote et pour l'ozone dans les couronnes des arbres. Mais il n'était pas possible de démonter une réduction mesurable de ce potentiel à l'extérieur des couronnes. En regardant les carbures d'hydrogène organique volatiles (VOC) le résultat le plus important de l'étude était l'absence d'une émission de terpène venant des arbres. On n'observait même pas d'émissions d'isoprène. En conclusion on pourrait dire que les châtaigniers montrent un potentiel de formation d'ozone très réduit.

Zusammenfassung. Diese Studie untersucht die Effekte von einzelnen und einer kleinen Gruppe von Bäumen auf das Bioklima einer Stadt. Die Untersuchungen zur thermischen und lufthygienischen Komponente des Stadtklimas wurden am 19. und 29. September 2000 am Fahnenbergplatz im nördlichen Stadtzentrum von Freiburg im Südwesten von Deutschland durchgeführt. Das Untersuchungsgebiet ist mit 12 Kastanienbäumen (Aesculus hippocastanum) unterschiedlichen Alters und Größe bestanden und war ca. $1700 \mathrm{~m}^{2}$ groß. Die positiven Effekte von Bäumen auf die thermische und lufthygienische Komponente des Stadtklimas wurden durch diese Studie bestätigt. Insbesondere die mittlere Strahlungstemperatur $\mathrm{T}_{\text {mrt }}$ und der human-biometeorologische thermische Index Physiologisch Äquivalente Temperatur PET zeigten deutliche Unterschiede zwischen baumbestandenen und nicht baumbestandnen Arealen, trotz der geringen Größe des Untersuchungsgebietes. Ein hohes Reduktionspotential für Stickoxide und Ozon wurde innerhalb der Baumkronen gefunden, allerdings war außerhalb der Baumkronen keine messbare Reduktion festgestellt worden. Das wichtigste Ergebnis bezüglich den VOCs (Flüchtige Organische Komponenten) war die Abwesenheit von Terpenemissionen bei Rosskastanien. Des Weiteren wurden auch keine Isoprenemissionen bei Rosskastanien nachgewiesen. Daraus lässt sich schließen, dass Rosskastanien ein sehr geringes Ozonbildungspotential besitzen.

Resumen. Este estudio tiene por finalidad analizar los efectos de árboles especiales en el bioclima de una ciudad. Las investigaciones acerca de los componentes térmicos y de la calidad del aire del clima urbano fueron llevadas a cabo el 19 y 29 de setiembre del 2000 en "Fahnenbergplatz" en el área norte del centro de la ciudad de Freiburg en el suroeste de Alemania. El área de estudio, de alrededor de $1700 \mathrm{~m}^{2}$, contenía doce castaños de Indias de diferentes edades y tamaños. El efecto positivo de los árboles en las condiciones térmicas y en la calidad del aire fue confirmada por el estudio. En particular, la temperatura media de radiación Tmrt y el índice térmico biometeorológico humano Temperatura Fisiológica Equivalente (PET) mostraron distintas diferencias entre áreas con árboles y áreas sin árboles, a pesar del tamaño pequeño del área de estudio. Se encontró una alta reducción potencial de los óxidos de nitógeno y ozono dentro de las capas de los árboles pero fuera de las copas no habían reducciones medibles. Los resultados más importantes en relación con los VOCs (Componentes Orgánicos Volátiles) fue la ausencia de emisiones de terpene de los castaños de Indias. Tampoco se encontraron emisiones de isoprene de los castaños de Indias. Estos árboles presentan, por lo tanto, una muy pequeña formación potencial de ozono. 


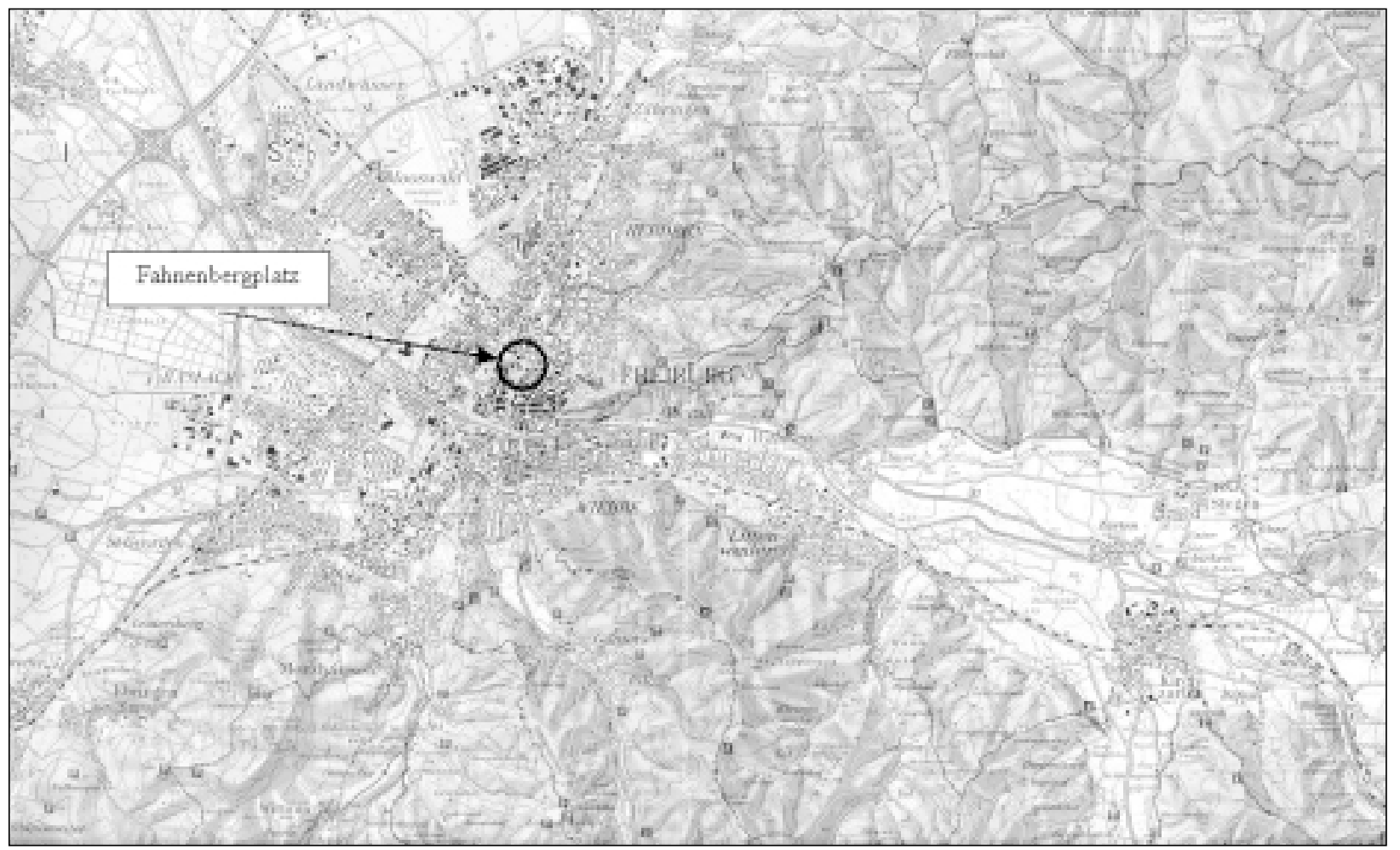

Figure 1. Overview of Freiburg and the surrounding area with the location of Fahnenbergplatz/Freiburg.

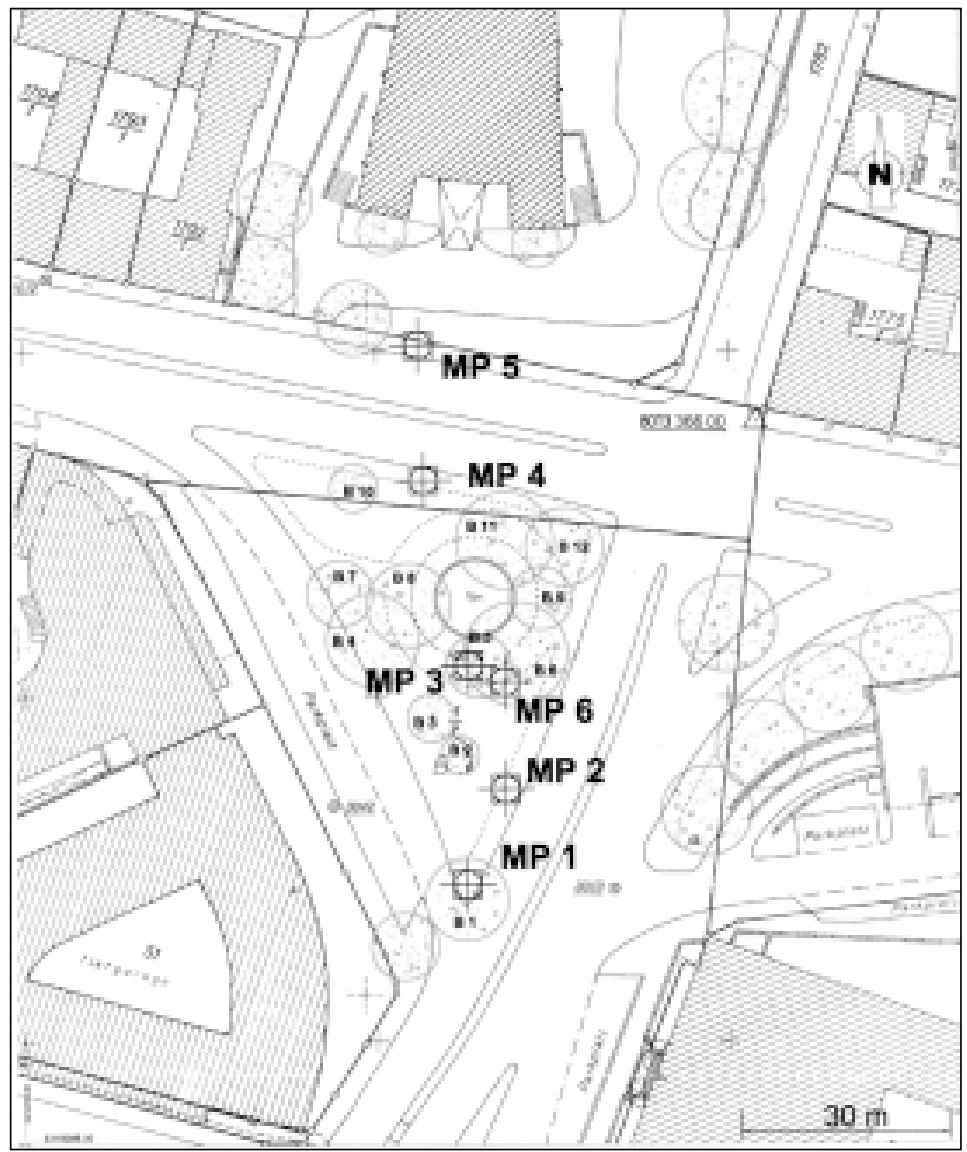

Figure 2. Location of the measuring points (MP 1-6) and the trees at Fahnenbergplatz/Freiburg. 


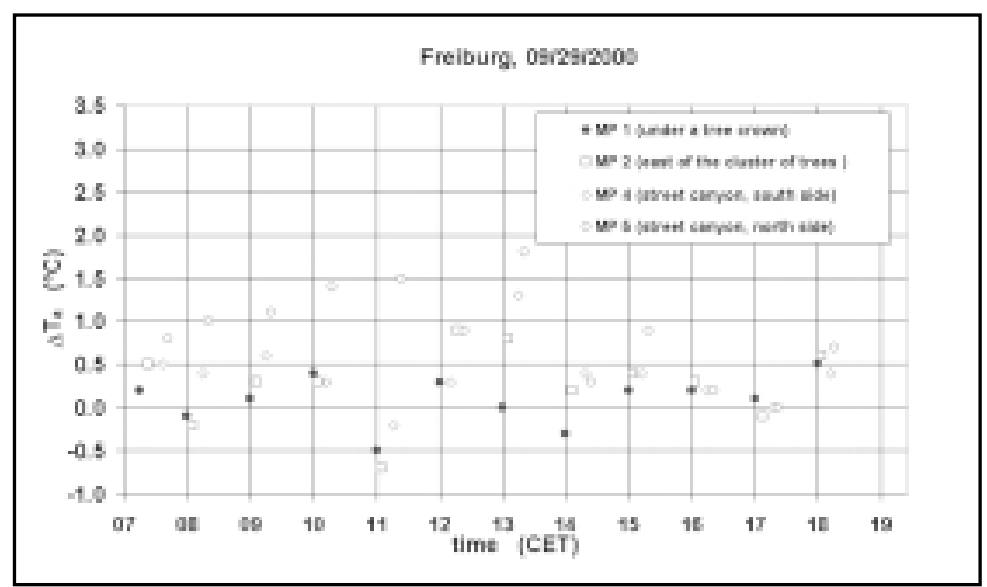

Figure 3. Example of the diurnal variation of air temperature, $T_{a}$, at the five measurement points in relation to MP 3 (under a cluster of tree crowns) at Fahnenbergplatz/Freiburg on September 29, 2000.

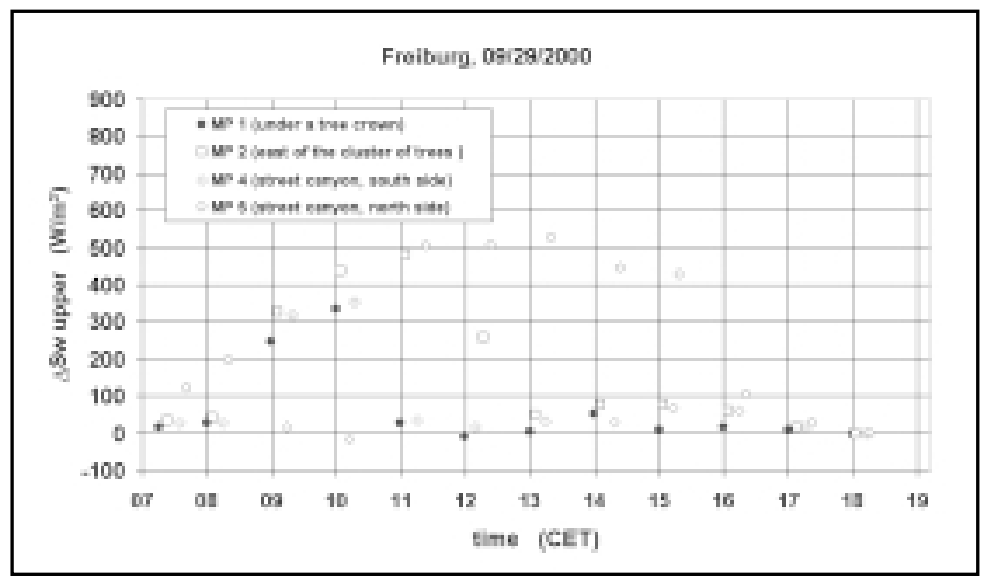

Figure 4. Example of the diurnal variation of shortwave radiation from the upper half-space at the five measurement points in relation to MP 3 (under a cluster of tree crowns) at Fahnenbergplatz/Freiburg on September 29, 2000.

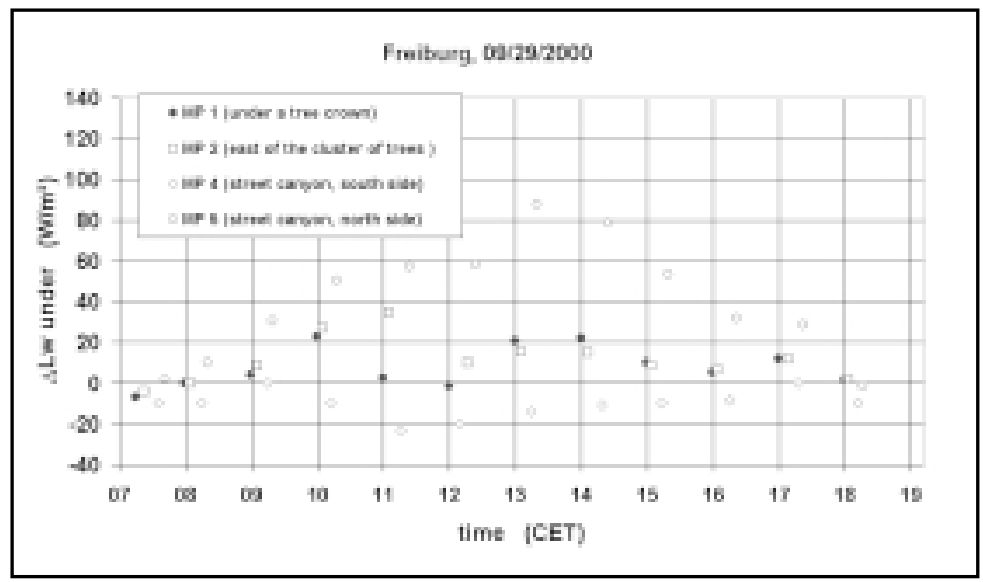

Figure 5. Example of the diurnal variation of long wave radiation from the lower half-space at the five measurement points in relation to MP 3 (under a cluster of tree crowns) at Fahnenbergplatz/ Freiburg on September 29, 2000. 


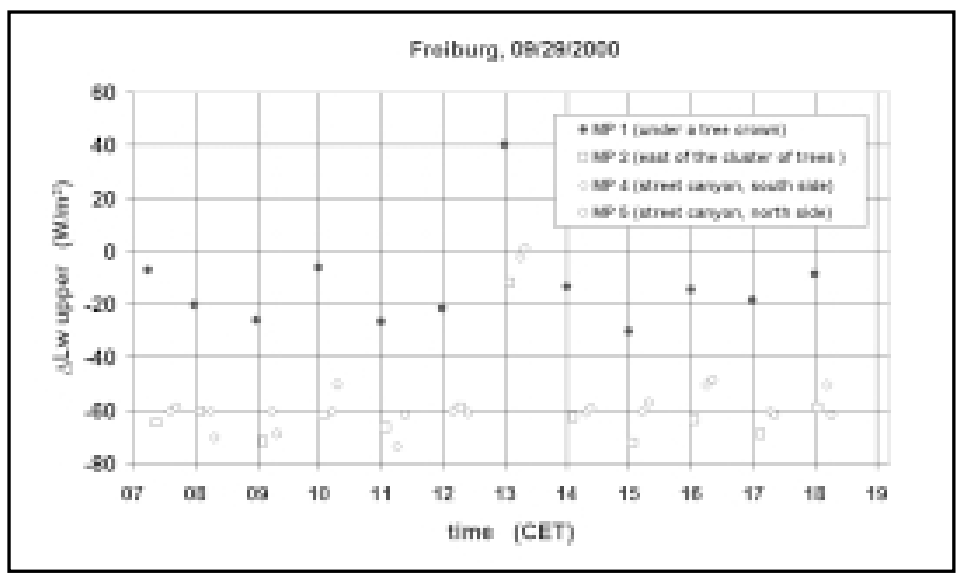

Figure 6. Example of the diurnal variation of longwave radiation from the upper half-space at the five measurement points in relation to MP 3 (under a cluster of tree crowns) at Fahnenbergplatz/Freiburg on September 29, 2000.

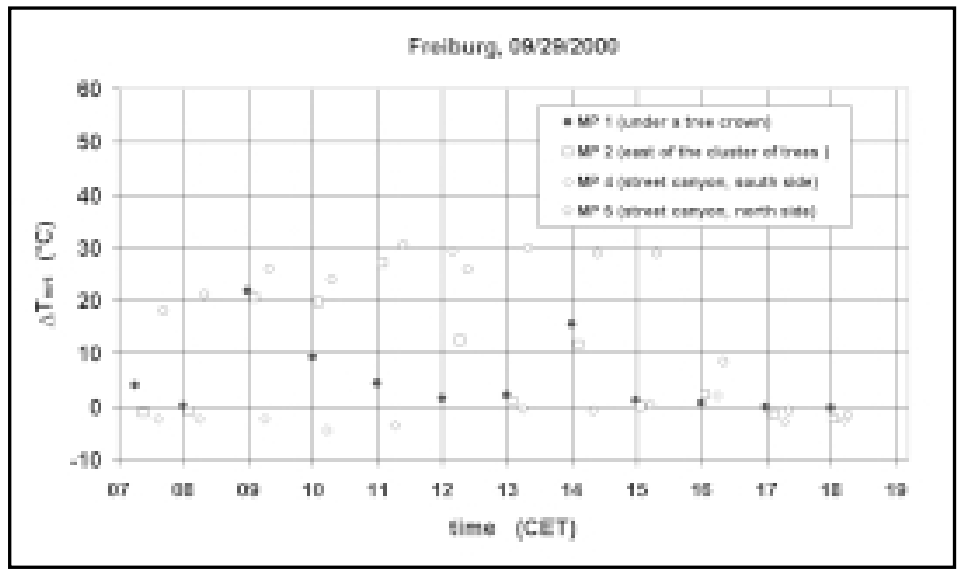

Figure 7. Example of the diurnal variation of mean radiation temperature, $T_{\text {mrt }}$ at the five measurement points in relation to MP 3 (under a cluster of tree crowns) at Fahnenbergplatz/ Freiburg on September 29, 2000.

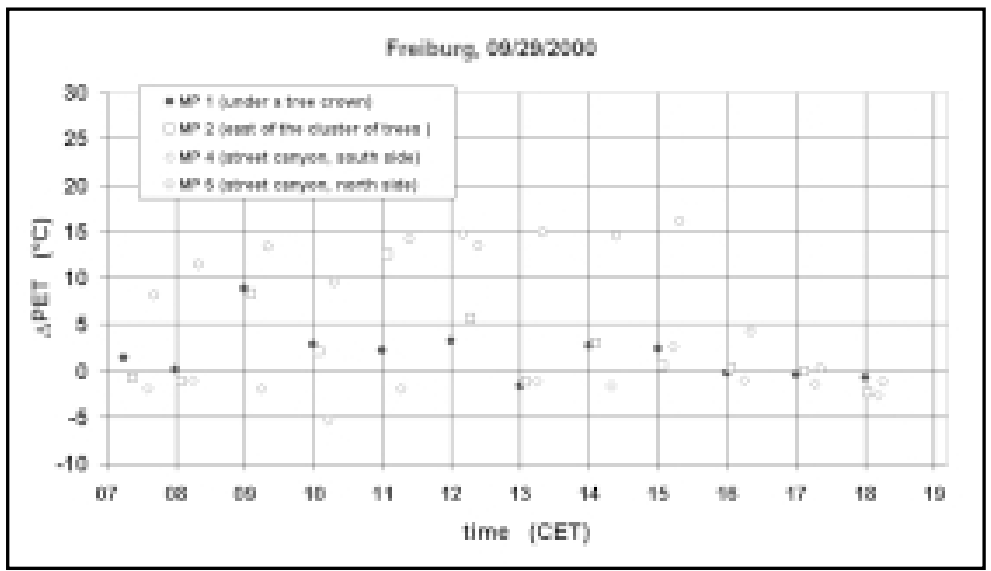

Figure 8. Example of the diurnal variation of PET at the five measurement points in relation to MP 3 (under a cluster of tree crowns) at Fahnenbergplatz/Freiburg on September 29, 2000. 


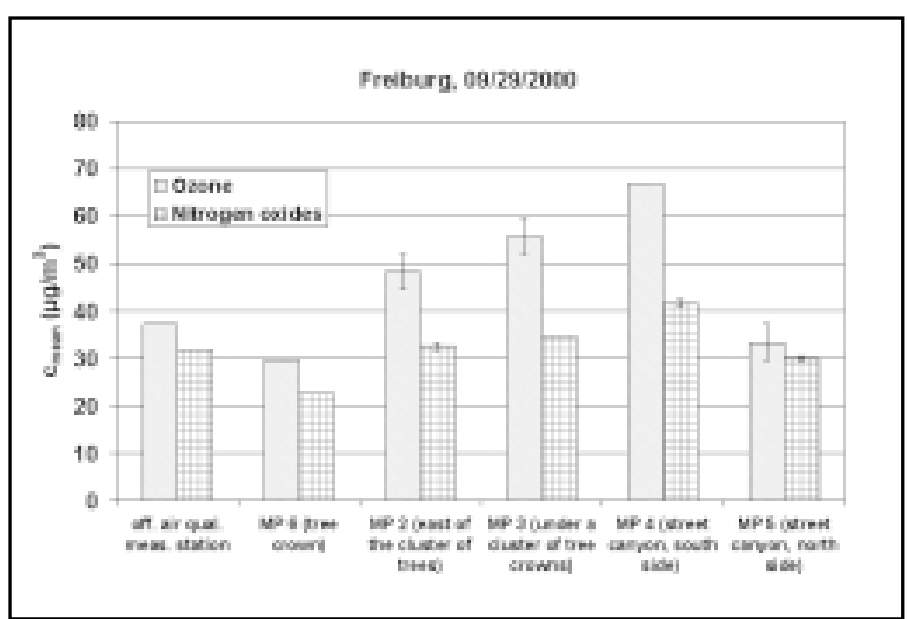

Figure 9. Mean values of concentration of nitrogen oxides and ozone at the five measurement points at Fahnenbergplatz/ Freiburg on September 29, 2000 (the error bars show the single standard deviation). 